\title{
Qualimetric Assessment of the Public Services Efficiency Provision in the Kyrgyz Republic
}

\author{
Aigul Musaeva1, Salmorbekova Rita², Kunduzkhan Karimova3 ${ }^{3}$, Zhypargul Abdullaeva ${ }^{*}$ (]) \\ ${ }^{1}$ International Relations Department, Osh State University, Osh, Kyrgyzstan \\ ${ }^{2}$ Department of Psychology, International Ala-Too University, Bishkek, Kyrgyzstan \\ ${ }^{3}$ Department of Social Work, Osh State University, Osh, Kyrgyzstan \\ ${ }^{4}$ Science and Research Department, Osh State University, Osh, Kyrgyzstan \\ Email: *jypar.science@oshsu.kg
}

How to cite this paper: Musaeva, A., Rita, S., Karimova, K., \& Abdullaeva, Z. (2021). Qualimetric Assessment of the Public Services Efficiency Provision in the Kyrgyz Republic. Open Journal of Political Science, $11,123-133$.

https://doi.org/10.4236/ojps.2021.111008

Received: October 26, 2020

Accepted: January 19, 2021

Published: January 22, 2021

Copyright () 2021 by author(s) and Scientific Research Publishing Inc. This work is licensed under the Creative Commons Attribution International License (CC BY 4.0).

http://creativecommons.org/licenses/by/4.0/

\begin{abstract}
In this article, the authors consider qualimetric assessment of public services as one of parameters for social policy effectiveness in Kyrgyzstan. The relevance in this work is based on analysis of the received information materials, improving the mechanisms of activity and modernizing the assessment of the efficiency index of local self-government to provide a new approach to measuring the analysis and improve social policy in the provision of public services, which can subsequently provide support in solving social, political and economic problems. In the government municipal service, the qualimerty method is not used for assessment of the population satisfaction in providing the governmental services; therefore, provision of standardization is considered as new approach.
\end{abstract}

\section{Keywords}

Analysis, Qualimetry, Local Government, Service Assessment, Efficiency of Service Provision

\section{Introduction}

The issues on improving the rendering system of government municipal services to the population, and improving the quality of life are important and one of the main goals in the social policy of Kyrgyzstan. The means of achieving this goal are the improvement of the mechanism for assessing the quality of local self-government activities, which used to substantiate decisions taken in the management of resource allocation. The level and quality of life of the population characterizes the development and degree of satisfaction of the material, 
spiritual and social needs of people. In other words, indicators for conditions with quality of life of the population are necessary and their provision has appropriate goods and services. The local population receives various types of services from government agencies, local governments, public and community organizations, businesses, and individuals. The quality, availability, and reliability of services largely depend on how constructive feedback is created between service providers and their recipients. The time has come when the population can directly influence the process of providing services by local governments. At the same time, citizens lack the skills and knowledge of the mechanisms of influencing local self-government (LSG) bodies in the field of improving these services (UNDFP, 2012).

\section{Literature Analysis}

Improving the quality of public services provided is impossible without the development of a legal and regulatory framework that will regulate the regulation of the provision of municipal services (Azgaldov \& Azgaldova, 1971). Public service identified as economic or managerial implications, also affecting the politics of service provision; public services protected education, health, policing and defense (Batley \& Mcloughlin, 2015).

Strategies to improve the quality of local public services discussed a framework relationship with customers to internal management approaches (Skelcher, 1992).

To increase the efficiency of provided municipal services, it is necessary, first of all, to establish a legislative framework for the system formation concerning services provided by the local governments; secondly, to approve targeting programs for improvement the quality of provisions by municipal services, and important role pertaining to development and approval of regulations, instructions, guidelines that would regulate the efficiency of local government service provision (UNDFP, 2012). The results of this study showed that one of the tools aimed at collecting, assessing the performance of the local and public sectors is social qualimetry. This methodology uses to a large extent cluster surveys to identify important changes in the management and delivery of services, subsequently providing information in the development of specific action plans to improve the quality and access to public services, since social policy needs information that can be used to assess the efficiency of public services.

Currently, the assessment of the quality of social services and social services for the population is the most urgent problem of modern society. Assessing service quality in the social sector may offer distinct challenges (Malley \& Fernández, 2010). Each service is determined by a special body that certifies the services provided and the qualities. This is a quality assessment according to the so-called "name scale" or "address scale". Putting order into a single system allows you to quantify the quality of the services in question. Methods of quantitative assessment are relevant; we propose a method of reducing several quantitative assess- 
ments of various parameters characterizing quality to one indicator. Qualimetry is an independent science of evaluating the quality of any object (Rozhkov, 2011). However, to solve many practical problems, unified methods needed to more reliably and accurately determine the levels of qualities and, on this basis, make adequate management decisions regarding the quality of services provided. Objectives in the multidimensional public administration demand are not only limited to cost-benefit analysis but also incorporates essential elements of providing value to citizens (Manzoor, 2014). Evaluating the effectiveness of public administration at the local level provides critical feedback to identify specific social policy reforms, as the view of public administration is multidimensional, including the quality of service delivery, equal access to all citizens, and rationalization of service delivery procedures.

The direct impact on the quality of public administration by the systemic parameter of the quality of public (municipal) services is the level of satisfaction with the quality of their provision. Other parameters in this regard are important, first of all, to the extent that they contribute to or hinder the growth of satisfaction of service recipients. This parameter can be considered as a systemic parameter, also because it directly and significantly affects the confidence of citizens and businesses in government and local government bodies, on the level of satisfaction with their activities. Indicators help to prioritize areas of reform to correct gaps and draw attention to identified problems. Because of feedback, it provides information on the quality and adequacy of services from real recipients of services aimed at improving the situation in the field of public services for the population.

\section{Methodology}

Within the framework of research, methods of sociological research used. The sociological method for determining indicators based on collecting, analyzing, and summarizing the opinions of actual or potential consumers. This method used when it is impossible by other means to determine any indicators, such as usability, needs, and requirements, etc. (Albegova et al., 2015).

The results of the study should serve as a tool for identifying priority problems and reflect the real state, opportunities, and prospects of the services provided on the ground. In this study, a pilot study conducted with a random sample of local government representatives. The object of the research is the institutions of local government.

\section{Social Policy Improvement}

The study primarily conducted to improve the social policies of country. Integral indicators to assess the quality of work of social service institutions include assessment of the management quality; assessment of the quality of financial and economic activities; assessment of the quality of staff work; performance assessment; assessment of the effectiveness of activities following the goals of its crea- 
tion. These indicators used to study and forecast the level, dynamics, and structure of income from various sources (Salmorbekova \& Musaeva, 2018).

The specificity of transformations in the field of municipal services, following the Law of the Kyrgyz Republic "On State and Municipal Services", was the division of local registers of municipal services into two types (Kyrgyz Republic Government Resolution, 2015).

1) Basic registry of municipal services, approved by the Government of the Kyrgyz Republic is the same for all municipalities;

2) An additional list of municipal services, which determined by the local authorities themselves.

The basic registry of municipal services is an approved minimum list of municipal services provided to consumers by local governments throughout the Kyrgyz Republic, on a free and paid basis, in accordance with the powers established by the legislation of the Kyrgyz Republic as shown in Figure 1. (Shadybekov et al., 2015). Basic register of municipal services provided by local self-government bodies of the Kyrgyz Republic shown in Table 1.

An additional list of municipal services is a list of municipal services provided to consumers by the decision of representative bodies of local self-government on a free or paid basis, formed in addition to the basic register of municipal services, based on the needs of the local community, the capabilities of the local budget, introduced within the administrative-territorial unit (Kyrgyz Republic Government Resolution, 2015).

But, an important problem is precisely the assessment of the efficiency and effectiveness of the provision of individual municipal services. With limited financial resources, the municipal government constantly has to decide which budget services and in what volume to provide, and which ones to refuse. Efficiency is determined using indicators characterizing the degree of satisfaction of certain needs of the population or losses from the lack of this service.

The most important indicator of this kind is an increase or decrease in the number of complaints and complaints from the population about quality. For certain types of services, particular performance indicators can be used: waiting time for urban transport at a bus stop, frequency of removal of household waste, the temperature in apartments during the heating season, estimated time for eliminating an accident in the operation of the housing stock, condition of city

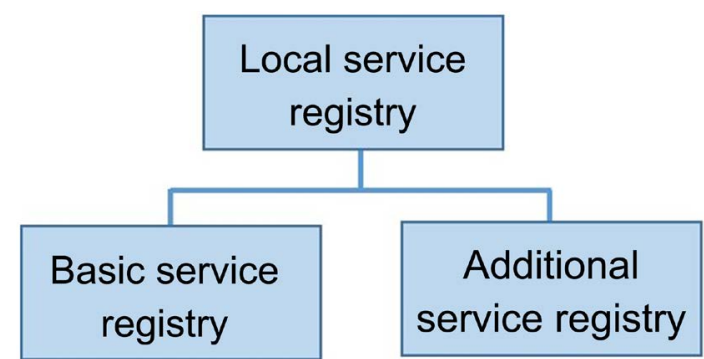

Figure 1. Local service registry structure. 
Table 1. Basic register of municipal services provided by state agency of local self-government and interethnic relations (SALSGIR) of the Kyrgyz Republic (Shadybekov et al., 2015).

\begin{tabular}{|c|c|c|c|c|}
\hline & Municipal service name & $\begin{array}{l}\text { The authorized body responsible } \\
\text { for the standardization } \\
\text { of municipal services }\end{array}$ & $\begin{array}{l}\text { Municipal institutions } \\
\text { providing services }\end{array}$ & $\begin{array}{l}\text { Conditions for the } \\
\text { provision of municipal } \\
\text { services (paid/free) }\end{array}$ \\
\hline \multicolumn{5}{|c|}{ ADMINISTRATIVE SERVICES } \\
\hline 1 & $\begin{array}{l}\text { Name and renaming of geographical objects in the } \\
\text { settlement at the suggestion of individuals and legal } \\
\text { entities }\end{array}$ & SALSGIR & $\begin{array}{l}\text { Representative organs of } \\
\text { local self government }\end{array}$ & Free \\
\hline \multicolumn{5}{|c|}{ SERVICES FOR GRANTING RIGHTS TO MUNICIPAL PROPERTY OBJECTS } \\
\hline 2 & $\begin{array}{l}\text { Registration of citizens in need of better housing } \\
\text { conditions }\end{array}$ & SALSGIR & $\begin{array}{l}\text { Executive organs } \\
\text { of local self government }\end{array}$ & Free \\
\hline 3 & $\begin{array}{l}\text { Provision of residential premises in municipal } \\
\text { ownership to citizens of the Kyrgyz Republic in } \\
\text { ownership }\end{array}$ & SALSGIR & $\begin{array}{l}\text { Executive organs } \\
\text { of local self government }\end{array}$ & Free \\
\hline 4 & $\begin{array}{l}\text { Provision of residential premises in municipal } \\
\text { ownership to individuals and legal entities for } \\
\text { fixed-term use }\end{array}$ & SALSGIR & $\begin{array}{l}\text { Executive organs } \\
\text { of local self government }\end{array}$ & Free \\
\hline 5 & $\begin{array}{l}\text { Putting citizens on the waiting list as those in need of } \\
\text { allocation of land plots for individual housing } \\
\text { construction }\end{array}$ & SALSGIR & $\begin{array}{l}\text { Executive organs } \\
\text { of local self government }\end{array}$ & Free \\
\hline 6 & $\begin{array}{l}\text { Provision of a land plot for individual housing } \\
\text { construction }\end{array}$ & SALSGIR & $\begin{array}{l}\text { Executive organs } \\
\text { of local self government }\end{array}$ & Free \\
\hline 7 & $\begin{array}{l}\text { Granting citizens the right to use or ownership of the } \\
\text { adjacent land plot }\end{array}$ & SALSGIR & $\begin{array}{l}\text { Executive organs } \\
\text { of local self government }\end{array}$ & Free \\
\hline 8 & $\begin{array}{l}\text { Provision of land plots in municipal ownership to } \\
\text { individuals or legal entities for lease or ownership }\end{array}$ & SALSGIR & $\begin{array}{l}\text { Executive organs } \\
\text { of local self government }\end{array}$ & Free \\
\hline 9 & $\begin{array}{l}\text { Provision to individuals and legal entities through } \\
\text { privatization of non-residential premises and real } \\
\text { estate objects that are in municipal ownership }\end{array}$ & SALSGIR & $\begin{array}{l}\text { Executive organs } \\
\text { of local self government }\end{array}$ & Free \\
\hline 10 & $\begin{array}{l}\text { Provision, upon request of individuals and legal } \\
\text { entities, for use and lease of non-residential premises } \\
\text { and real estate objects that are in municipal ownership }\end{array}$ & SALSGIR & $\begin{array}{l}\text { Executive organs } \\
\text { of local self government }\end{array}$ & Paid \\
\hline 11 & Provision of a land plot for burial in cemeteries & SALSGIR & $\begin{array}{l}\text { Executive organs } \\
\text { of local self government }\end{array}$ & Free \\
\hline \multicolumn{5}{|c|}{ SOCIAL AND CULTURAL SERVICES } \\
\hline & $\begin{array}{l}\text { Issuance for temporary use of printed publications } \\
\text { and documents that are in the funds of libraries } \\
\text { established by local governments }\end{array}$ & $\begin{array}{l}\text { Ministry of culture, } \\
\text { information and tourism }\end{array}$ & $\begin{array}{l}\text { Executive organs } \\
\text { of local self government }\end{array}$ & Free \\
\hline
\end{tabular}

roads, time from calling an ambulance to the moment her arrival, etc. These indicators should be established by municipal social standards (Markina \& Ostashkov, 2008).

Local governments should be able to assess the effectiveness of each service, measure the result obtained against the cost of achieving it (i.e. evaluate the effectiveness of the service delivery), and, based on this comparison, choose priorities. Not all functions defined by this Law as the own functions of the local self 
government (LSG) are perceived as such by LSG bodies. The LSG functions include initiating and implementing the development programs, stimulating and supporting development within its boundaries to strengthen democracy (Islam, 2015). The level of human development in the Kyrgyz Republic throughout its territory determined by the development of LSG. It is here, at the LSG level, which the most important basic services are provided that create, an environment for human development. Here, a person receives primary and secondary education, which largely determines his further life path, here opportunities for personal development open up or do not open up. Here primary medical care provided and disease prevention carried out, the basic components of human health laid through the protection of mothers and children, obstetric services, and environmental conditions. It is here that children are brought up, the younger generation develops, the cultural and social skills of the future personality and future citizen are formed, traditions are born, live and die here, either helping the individual to realize himself and achieve a high level of development, or opposing himself to progress (National Report on Human Development KR, 2012).

Thus, it should be noted that special emphasis should be placed on maximum consideration of the interests of the local community, various social groups, and, in particular, socially vulnerable segments of the population.

Advanced tools that study governance and service issues tend to be at the national level and thus fail to detect changes at the subnational level and across different agencies. Simply put, they often fail at the country level to identify significant differences at the local or national level.

The social policy of Kyrgyzstan and the qualimetric assessment of public services have a number of other key functions: First, it provides a complete picture of governance and service delivery across sectors and criteria, giving a clearer understanding of their relationship. For example, it is well known that health and safety can affect school performance; unhealthy children or people who cannot travel safely to and from school are likely to accomplish more than those who enjoy quality health care and public safety. Studying citizens, experiences across sectors provides a better understanding of these links and the complex root causes of poor productivity. Thus, social qualimetry provides a tool for sector-based programming that provides and complements information collected using industry-specific tools (citizen scorecards).

Second, it emphasizes the experience of citizens over their satisfaction. Satisfaction is influenced by two factors: citizens' expectations and their experience. Some tools also focus on experience; thus, it is not unique in this regard. However, this is an important difference from citizen scorecards, which is usually highlight satisfaction.

Third, it designed to be scientifically implemented and include the experience of both users and non-users. As such, it differs from citizen scorecards, many of the tools that focus on user experience through tools such as polls. User experience is important, but it is equally important to understand the experiences 
and decisions of those who move elsewhere for services.

Fourth, it provides a better understanding of how citizens participate in delivery and management services. Despite the current concerns about participatory planning, the implementation of existing tools tends to limit our understanding of citizen participation. By asking the challenges that citizens often face with regard to education, health, safety and other issues; and how they seek to address these issues, social qualimetry paints a better picture of citizen participation and provides insight into entry points to improve participation and accountability.

Fifth, it allows us to explore the role of state and non-state institutions and actors in service delivery and management. Frequently, citizens turn to non-state actors to provide public services, enhance public safety, and participate in activities that improve community governance and services. It is important to look behind formal institutional arrangements and actors to understand when communities are managing themselves successfully and can meet their needs. Specific objectives provide a clear understanding of the main aspects of service delivery. Aspects of service: availability, accessibility, use of the service, quality of service, staff behavior, corruption, quality and degree of satisfaction of the services provided in general. The social policy assessment in public services has a number of key functions including the organizational structure of the local self government.

\section{Organizational Structure of the Local Self-Government}

One can also agree that the organizational structure of management causes certain difficulties. When considering the organizational structure of LSG, shortcomings, and problems that need to be addressed were identified. Based on the research conducted, we have compiled a SWOT analysis of the activities of LSG. The study covers the services provided at the local level and presented in Table 2.

Consequently, it is important to observe institutional arrangements to understand how to successfully manage yourself and meet own needs. The main assessment indices divided into 6 main policy orientations:

1) Education

2) Health

Table 2. SWOT analysis of LSG activities.

\begin{tabular}{ll}
\hline & Weak sides: \\
Strong sides: & - Internal problems (organizational): \\
- HR policy (motivation, qualifications) & - Depreciation of equipment \\
- Cost management & - Frames \\
& - Financial difficulties \\
& \\
Threats: & Capabilities: \\
- State policy (taxes, customs, etc.) & - Increase wages \\
- Financial problems associated with investments & - Improve personnel policy \\
- Frame problems & - Solve personnel problems \\
& - Improve working conditions
\end{tabular}


3) Dispute resolution

4) Social protection and welfare

5) The relationship between citizens and the government

6) Social culture

The local governance performance index allows us to look at a range of governance and service issues. The local governance performance index allows us to look at a range of governance and service issues. Recognizing the experience of citizens and their perception about quality of service, the fight against corruption, and many other issues, we can determine the degree of perception and identify the nature and norms of behavior. By learning a range of topics (education, health care, dispute resolution, welfare), we can create a table of percentage ratios of cities and towns. Negative effect can be the identification of sources of inequality between populations: geographical differences, differences in the quality of education or health care, employment, etc. The data also allows identification of unequal access to services, participation rates, and other outcomes related to gender, socioeconomic, status, and age differences. Finally, it can help us see differences in the quality of private objects, both experienced and perceived.

The local governance performance index can and should be adapted to specific countries in two ways. Firstly, the questions in the context of local governance performance index need to be adapted to the relevant terminology, include all possible outcomes, and eliminate inappropriate points and phenomena. Secondly, specific questions of interest can be included in the local governance performance index survey.

The local governance performance index should be conducted in collaboration with relevant officials, service providers, civil society activists, other interested parts and citizens. Such reviews can be conducted through a focus group to explore key governance issues and concerns. Adjustments are possible and often necessary, but they also should be done economically.

The local governance performance index can be used both to detect subnational changes and ultimately to be compared across countries. Both comparisons can be useful for government officials, civil society leaders, and citizens.

The main functions of the services provided depend on the socio-economic situation of the country; formation of the revenue and expenditure side of the local budget; climatic and geographical conditions and from the season of the year; knowledge, awareness of the population on the issues of services provided by various departments in the field of public services. The main services of local importance in places affect the increase in the standard of living of the population, lowering the distrust of citizens in various departments in the field of public services, reducing morbidity, reducing external and internal migration, maintaining stability and spiritual balance of society, etc.

Thus, we propose a "local governance performance index" method for measurement to assess the improvement of the local government. The tool aims to identify reliable information based on world standards. Even in highly centra- 
lized systems, the nature and quality of governance and service delivery vary considerably at the local level. Some local leaders are finding ways to overcome resource scarcity, ensure transparency and accountability, and provide better services than other communities. In addition, decentralization efforts aimed at expanding local rights and responsibilities. Finally, we recognize that communities do not perform equally well in all areas of management and service delivery: some areas are leading, others are stagnating or declining.

Expanded management and service tools are typically defined in national level, and thus fail to detect changes at the subnational level and across different agencies. We need a tool that can measure variation both within and across the local communities. We propose to test the indicators of the local governance performance index to determine the needs for local services and develop appropriate programming to evaluate the results.

The results of the study will be useful in improving the social policy of the state, more precisely, LSG bodies:

- identification of own strengths and weaknesses in the provision of services

- determination of priorities in own activities

- receiving specific proposals for improving services

- determining the needs of the population for new types of services

- bringing the necessary information to the recipients to whom services are providing

- obtaining sufficiently objective information about nature, degree, and prevalence of corruption and other hidden costs, etc.

\section{Conclusion}

Since the quality and effectiveness of public services provided by local governments may vary, monitoring can help provide additional means to collect feedback and provide data to improve public social policies aimed at improving the quality of life of the population. Feedback methods are developed in many countries.

Institutionalized processes for monitoring local government and public social policy can:

- contribute to the expansion of citizens law and public opinion strengthening;

- provide feedback, collect evidences, interpret results and develop solutions;

- improve politicians understanding about interested parties concerns and initiate steps to solve that problems leading to the effective provision of government municipal services;

- increase the legitimacy of government actors and strengthen trust and cooperation between citizens, civil society organizations and executives;

- promote local democracy and collective decision-making: promote transparency and accountability to society and instilling a sense of responsibility to all stakeholders;

As a result of the obtained research, it can be argued that with the help of 
monitoring by methods of social qualimetry, it can be achieved:

- introduction of public services inclusiveness assessment from the side of civil society and citizens;

- obtaining data on service delivery in an understandable and accessible form to support monitoring by civil society and assess its effectiveness;

- maintaining exchange of monitoring results of citizens with service providers;

- needs identification and monitoring is carried out by service providers and social policy providers;

- working in partnership with civil monitoring initiatives to develop cooperation and address identified problems;

- institutionalized planning and evaluation of providing public services and their effectiveness;

- development of mechanisms for monitoring needs of citizens and providing public services in local governments with existing supervision and state responsibility.

The inclusiveness of qualimetric assessment effectiveness of public services provision in the Kyrgyz Republic will lead to:

- reduction of interagency red tape;

- reducing the time spent on receiving public services;

- the disappearance of intermediaries involved in corruption schemes;

- due to the lack of direct interaction with the service providers, achieving a significant anti-corruption effect;

- increasing the citizens satisfaction by interaction with government agencies.

\section{Conflicts of Interest}

The authors declare no conflicts of interest regarding the publication of this paper.

\section{References}

Albegova, I. F., Serova, E. A., \& Shamatanova, G. L. (2015). Social Qualimetry, Quality Assessment and Standardization of Public Services. Tutorial (116 p.). Yaroslavl: YarSU.

Azgaldov, G. G., \& Azgaldova, L. A. (1971). Quantitative Evaluation of Quality (Qualimetry). Bibliography (176 p.). Moscow: Publishing House of Standards.

Batley, R., \& Mcloughlin, C. (2015). The Politics of Public Services: A Service Characteristics Approach. World Development, 74, 275-285. https://doi.org/10.1016/j.worlddev.2015.05.018

Islam, F. (2015). The Role of Local Self-Government Institution for Deepening Democracy at the Grass-Root Level in Bangladesh. Journal of Public Administration and Policy Research, 7, 29-38. https://doi.org/10.5897/JPAPR2015.0311

Kyrgyz Republic Government Resolution. (2015). On Approval of the Basic Registry Municipal Services Provided by Local Government Bodies of Kyrgyz Republic. Bishkek, January 14, 2015, No. 6 .

Malley, J., \& Fernández, J.-L. (2010). Measuring Quality in Social Care Services: Theory 
and Practice. Annals of Public and Cooperative Economics, 81, 559-582.

https://doi.org/10.1111/j.1467-8292.2010.00422.x

Manzoor, A. (2014). A Look at Efficiency in Public Administration: Past and Future. SAGE Open, 4, 1-5. https://doi.org/10.1177/2158244014564936

Markina, V. V., \& Ostashkov, A. V. (2008). Monitoring of State and Municipal Services in the Region as a Strategic Tool for Improving the Quality of Regional Governance: EXperience, Problems, and Recommendations (321 p.). Moscow.

National Report on Human Development KR. (2012). Local Self-Government. (Last Checked 12 JANUARY 2012) http://dpi.kg/ru/activities/nat-report-lsg/

Rozhkov, N. N. (2011). Qualimetric Approach to the Problem of Comprehensive Assessment of the Quality of Public Services (pp. 26-32). Government and Municipal Service. Moscow.

Salmorbekova, R. B., \& Musaeva, A. K. (2018). Modernization of the Assessment of the Effectiveness of Local Government in the Context of World Strategies (pp. 267-268). Forms and Methods of Social Work in Various Spheres of Life. Ulan-Ude.

Shadybekov, K. B., Tretyakov, A. V., Murzaev, S. K., Kaparova, A. A., \& Momunova, N. S. (2015). Optimization of the System of Provision of State and Municipal Services in the Kyrgyz Republic: Theory and Practice (416 p.). Textbook, Bishkek.

Skelcher, C. (1992). Improving the Quality of Local Public Services. The Service Industries Journal, 12, 463-477. https://doi.org/10.1080/02642069200000059

United Nations Democratic Fund Project, UNDFP (2012). Development Pact: An Instrument of Accountability in the Hands of Communities (50 p.). Kyrgyzstan. 